\title{
Standardization of Rajapravartini Vati Tablets
}

\author{
Research Article
}

\author{
Dani Mayuri ${ }^{*}$, Pimparkar Surendra ${ }^{2}$, Gadkari Kishor $^{3}$, Pable Tarun $^{3}$ \\ 1. Lecturer, Swami Vivekanand Ayurved Medical College, Shrigonda Ahmednagar, Maharashtra \\ 2. DNB, ENT \\ 3. Unijules Life Sciences Limited, Kalmeshwar, Nagpur.
}

\begin{abstract}
"Standardization" expression is used to describe all measures, which are taken during the manufacturing process and quality control leading to a reproducible quality. Standardization of Ayurvedic drugs is a need of the hour in the field of Pharmacy. In Classical Ayurvedic texts the parameters given are mostly subjective. Hence there is a need to set some objective parameters through pharmaceutical and Analytical study. Rajapravartini Vati (Tablets) is prescribed for the treatment of scanty bleeding and amenorrhea. Dosage form plays a important role in delivery and proper action of particular drug. In this research paper, an attempt has been made to develop pharmaceutical and analytical standards for Rajapravartini Vati and transform it into Tablet form. In-house preparation and which was standardized on the basis of macroscopic, microscopic, physic-chemical parameters and Fingerprinting. Three samples were prepared and evaluated on the basis of ayurvedic as well as modern parameters. All three samples shows identical parameters and shows no significant difference. The set parameters were found to be sufficient to evaluate the Rajapravartini Vati Tablet and can be used as reference standards for the quality control/quality assurance in future
\end{abstract}

Keywords: Rajapravartini Vati, Standardization, Polyherbal formulation, Ayurveda, Rasashastra, Quality control.

\section{Introduction}

Nowadays there is increase in trend towards use of herbal medicine. Because various side effects and adverse effects of modern medicine which are becoming known each day. Hence, it is the responsibility of the regulatory authorities to guarantee availability of pure, safe, potent and effective herbal medicines to the consumer. There are lots of challenges in the standardization of a polyherbal formulation since the raw material collection has a batch to batch variations in their standards in terms of identification, storage, processing, lack of reference standards. which leads to the variations in the final products standards. To overcome these shortcomings of herbal medicines, various quality standards as laid down in formularies, pharmacopeia's or manufacturing operation are followed through statutory imposed good manufacturing practices by regulatory authorities. Since there is a major portion of herbal drugs in the global market it is important to adopt quality control guidelines in the manufacturing of herbal drugs which are acceptable internationally (1).

\footnotetext{
*Corresponding Author:

Dani Mayuri,

Lecturer,

Swami Vivekanand Ayurved Medical College,

Shrigonda Ahmednagar,

Maharashtra, India.

E-mail: mayuridani.md@gmail.com
}

In Modern era, women's are suffering from various menstrual disorders. Also modern medicines are not much effective and have their side effects on health. Hence there is increase in demand for Ayurvedic medicine for Gynaecological disorders. So the appropriate parameters for standardization of a classical formulations used in Gynaecological disorders like Rajapravartini Vati (2) is attempted through this study. Which have its classical reference in Bhaishajya Ratnavali Stri Rogadhikara.

The major problems in using Ayurvedic medicine is the unavailability of herbal medicine prepared with unique pharmaceutical and analytical validation. On this contrary to avoid batch to batch variations, the department of AYUSH, is working on the development of standard operating procedures for Ayurvedic preparation. This can be achieved if the herbal products are evaluated and analyzed using both Ayurvedic as well as modern techniques of standardization during and after preparation of finished product. Standardisation of Rajahpravartani vati (Tablet) form is an important step for establishment of biological activity, constituent physico-chemical profile, and pharmaceutical and analytical validation of herbal drugs. Hence standardisation tests helps in authenticating the polyherbal preparation and also in ensuring the quality of the same. Due to increased demands of herbal remedies worldwide, it is responsibility to provide the quality of the product in standard dosage form is bestowed upon Ayurvedic industry. Dosage form plays an important role for 
specific action and their efficacy on the human body. Amongst all the dosage forms tablet is widely accepted like syrup, powder, injectable etc. tablets are easy to administer, delivers exact dose, more palatable, easy to transport, packaging etc.

\section{Aim}

To standardize an ayurvedic polyherbal formulation- Rajpravartini vati.

\section{Objective}

- To prepare three batches of Rajpravartini vati.

- To perform pharmaceutical and analytical on Rajpravartini vati.

- To standardise the formulation of Rajpravartini vati.

\section{Materials and methods}

Table No. 1. Procedure of Rajpravartini Vati preparation.

\begin{tabular}{|c|l|}
\hline \multicolumn{1}{|c|}{ Raw } \\
Materials & $\begin{array}{l}\text { Shuddha Kasisa (Purified Green } \\
\text { Vitriol) 250 gm; Shuddha Hing } \\
\text { (Purified Ferula assafoetida )250 } \\
\text { gm; Shuddha Tankana (Purified } \\
\text { Borax) 250 gm; Kumari swarasa } \\
\text { (Liquid extract of Aloe vera) 250 } \\
\text { gm. }\end{array}$ \\
\hline Method Used & $\begin{array}{l}\text { Shodhana (Purification), Churna } \\
\text { nirmana (Preparation of powder } \\
\text { form), Bhavana (Liquid extract in } \\
\text { which material is processed), Mar- } \\
\text { dana (Trituration) }\end{array}$ \\
\hline Apparatus & $\begin{array}{l}\text { Pulveriser, Mass Mixer, Mass mil- } \\
\text { ler, Dryer, Edge runner, Tabulat- } \\
\text { ing machine. }\end{array}$ \\
\hline
\end{tabular}

\section{Procedure}

Stage I: Checking weight dispensed of Raw material.

\section{Stage II:}

- Shodhan of Kasisa: The raw Kasisa of quantity $500 \mathrm{gm}$ was taken for Shodhana. Shodhana process was carried out; by 3 hours sudation with Bhringaraja Swarasa (extract of Elipta alba Niss.) (3).

- Shodhan of Tankan: Shodhan process of Tankan was carried out by heating it on mild gas flame till its water content gets evaporated and it swells like a flower (4).

Stage III: Pulverization of Raw Material: All the raw materials mentioned in table no. 1 were taken in prescribed quantity and mixed together. These raw materials were pulverized in mass pulveriser to obtain its powder.

Stage IV: Mixing of Powder in Mass Mixer: Pulverized powder was weighed again to check processing loss and uniformly mixed in mass mixer.

Stage V: Sifting of Powder: The obtained material was then sifted in mass sifter using mesh No. 80 to obtain its fine powder.

Stage VI: Preparation of Liquid Extract: Ghritkumari $250 \mathrm{gm}$ was taken in Stainless steel vessel, 4 times (of Ghritkumari) water was added and boiled, till it was reduced to $50 \%$. Filtered and used for Bhavan process.

Stage VII: Bhavana: Mixed the shifted powder (Stage V) with liquid extract of Ghritkumari for in Edge runner machine for about 3 hours.

Stage VIII: Drying: Dried the bulk in the tray dryer for 3 hours at $60-80^{\circ} \mathrm{C}$

Stage IX: Addition of Excipients: Starch and Microcrystalline cellulose were added as an excipient in above mixture for proper binding of tablets. In batch of $1 \mathrm{~kg}$ starch $120 \mathrm{gm}$ and Microcrystalline cellulose $80 \mathrm{gm}$ was added. The mixture was uniformly mixed in suitable Stainless steel vessel. It was then subjected to drying in electric air dryer at $60^{\circ} \mathrm{C}$.

Stage X: Granulation in Multi Miller: Above material was passed through Multi miller through sieve no. 2 for granulation of material.

Stage XI: Compression: Uniform tablets each of 280-300 mg were prepared using automated tablet pressing machine, in which the active ingredient was $250 \mathrm{mg}$. About total 4000 to 4500 tablets were obtained of each sample batch A, B and C. Tablets were packed in air tight bottle and stored in cool dry place. All the hygienic conditions were maintained during preparation.

Stage XII: Sampling \& Analysis: Samples were tested on various analytical parameters.

Table.2: Showing the result of preparation of Rajpravartini Vati

\begin{tabular}{|c|c|}
\hline $\begin{array}{c}\text { Weight of total } \\
\text { contents taken }\end{array}$ & $\begin{array}{c}\text { Quantity of drug } \\
\text { obtained }\end{array}$ \\
\hline $1000 \mathrm{gm}$ & $4000-4500$ tablets of \\
280 to $300 \mathrm{mg}$ each
\end{tabular}

\section{Observations and Results}

Physico-chemical analysis: (5) To check quality of the formulation all three samples of finished products were checked using relevant modern parameters viz color, Uniformity in weight, Diameter, Thickness, Hardness, Friability, Disintegration time and Fingerprinting. The Results are tabulated below in table no. 3 
Table No.3: Comparative physico-chemical values of three batches of Rajapravartini Vati.

\begin{tabular}{|c|c|c|c|c|c|}
\hline $\mathbf{S r}$ & Test Name & Sample A & Sample B & Sample C & $\overline{M e a n ~ S D ~} \pm$ \\
\hline 1 & Description & $\begin{array}{l}\text { Blackish grey, } \\
\text { circular, Flat, } \\
\text { uncoated tablet } \\
\text { compressed flat, } \\
\text { uncoated tablet }\end{array}$ & $\begin{array}{l}\text { Blackish grey, } \\
\text { circular, Flat, } \\
\text { uncoated tablet }\end{array}$ & $\begin{array}{l}\text { Blackish grey, } \\
\text { circular, Flat, } \\
\text { uncoated tablet }\end{array}$ & - \\
\hline 2 & Average Weight & $0.2518 \mathrm{gm}$ & $0.2528 \mathrm{gm}$ & $0.2546 \mathrm{gm}$ & 0.2531 \\
\hline 3 & $\begin{array}{l}\text { Uniformity in } \\
\text { weight }\end{array}$ & $0.2459-0.2522 \mathrm{~g}$ & $0.2408-0.265 \mathrm{~g}$ & $0.2441-0.2667 \mathrm{~g}$ & $\begin{array}{c}\text { Complies } \\
0.246-0.2613 \mathrm{~g}\end{array}$ \\
\hline 4 & Diameter & $8.25 \mathrm{~mm}$ & $8.11 \mathrm{~mm}$ & $8.09 \mathrm{~mm}$ & $8.15 \mathrm{~mm}$ \\
\hline 5 & Thickness & $3.65 \mathrm{~mm}$ & $3.10 \mathrm{~mm}$ & $3.09 \mathrm{~mm}$ & $3.28 \mathrm{~mm}$ \\
\hline 6 & Hardness & $2.00 \mathrm{Kg} / \mathrm{Sq} . \mathrm{cm}$ & $3.50 \mathrm{Kg} / \mathrm{Sq} . \mathrm{cm}$ & $3.50 \mathrm{Kg} / \mathrm{Sq} . \mathrm{cm}$ & $3 \mathrm{Kg} / \mathrm{Sq} . \mathrm{cm}$ \\
\hline 7 & Friability & $0.17 \% \mathrm{w} / \mathrm{w}$ & $0.04 \% \mathrm{w} / \mathrm{W}$ & $0.15 \% \mathrm{w} / \mathrm{W}$ & $0.12 \% \mathrm{w} / \mathrm{W}$ \\
\hline 8 & $\begin{array}{l}\text { Disintegration } \\
\text { time }\end{array}$ & 23 to $24 \mathrm{~min}$ & 20 to $22 \mathrm{~min}$ & 16 to $18 \mathrm{~min}$ & $\begin{array}{c}\text { Passes } \\
19 \text { to } 21 \mathrm{~min}\end{array}$ \\
\hline 9 & TLC & Complies & Complies & Complies & \\
\hline & $\begin{array}{l}\text { TLC Spots } \\
\text { observed }\end{array}$ & $\begin{array}{c}0.00,0.08,0.16 \\
0.44,0.54,0.60\end{array}$ & $\begin{array}{c}0.01,0.16,0.26 \\
0.30,0.35,0.37 \\
0.42,0.54,0.71 \\
0.80\end{array}$ & $\begin{array}{c}0.00,0.08,0.16 \text {, } \\
0.42,0.44,0.54 \text {, } \\
0.71,0.80\end{array}$ & $\begin{array}{c}\text { vide range of } \\
\text { spots observed } \\
\text { as it contains } \\
\text { more than one } \\
\text { herbs and } \\
\text { minerals }\end{array}$ \\
\hline
\end{tabular}

Fingerprinting (6) study of Rajapavartini Vati was performed using Ethyl acetate : Methanol : Water 6 ; $1.4: 1$ ratio as mobile phase as Methanol as a solvent. TLC plate $(5.0 \times 10 \mathrm{cms}, 0.2 \mathrm{~mm}$ thickness $)$, HPTLC plates silica gel $60 \mathrm{~F} 254$. The bands were observed in wavelength from 254 and $366 \mathrm{~nm}$.

HPTLC PLATES UNDER DIFFERENT WAVELENGHTS
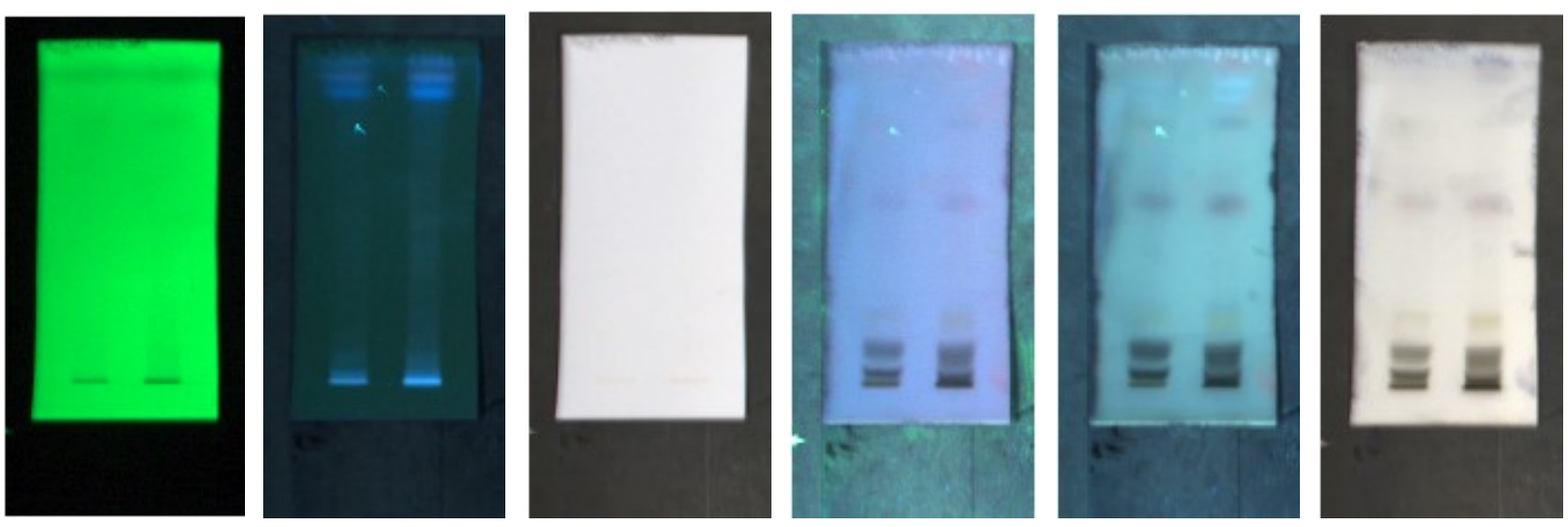

Wavelengths under $254 \mathrm{~nm}, 366 \mathrm{~nm}$, white $R$ of sample $A$, B and $C$ respectively.

\section{Discussion}

In traditional system of medicine, the quality control aspect has been covered by careful observation of physical parameters during and after preparation of medicine (7).According to modern pharmaceutics concept; quality control of medicine are developed in terms of modern methodologies. Thus, today quality assurance is a trusted area for the evaluation of traditionally used medicinal plants and herbal formulations. But in today's Ayurvedic Pharmaceutical Manufacturers set their own standards parameter for quality assurance by testing their own formulation; out of which most of them are only preliminary in nature. Combined and well-coordinated efforts from scientific workers of different disciplines are required to set universal parameters for quality assurance in Ayurvedic Pharmaceutical field. 
Rajpravartini Vati was found to have (mean \pm SD) $0.2531 \mathrm{~g}$ average weight. $90 \%$ tablets were within acceptable range of weight variation; According to Ayurvedic pharmacopeia of India (API) $\pm 10 \%$ range of weight variation is acceptable. Rajpravartini Vatti was found to have $3.00 \mathrm{~kg} / \mathrm{cm}^{2}$ hardness and $20 \mathrm{~min}$ disintegration time which was noticed with in accepted limits (8). There should not be large variation in between batches for various parameters like Disintegration time, Friability, Hardness, Thickness \& Uniformity in weight. Variation in weight of tablet causes improper doses of active medicament which changes the bioavailability of medicine. This may be due to causes such as variation in granule size, poor flow, bridging, rat holing, punch variation and poor mixing. Both hardness and disintegration time interfere with the bioavailability of drug. Hence there should be universal parameters for quality assurance of Ayurvedic formulations. By evaluating all above parameter results are tabulated in table No.4 below.

Table No.4. Showing Set of parameters for Rajahpravartani Vati Tablet

\begin{tabular}{|c|c|c|}
\hline $\mathrm{Sr}$ & Test Name & Set Parameters \\
\hline 1 & Description & $\begin{array}{c}\text { Blackish grey, to } \\
\text { Brownish gray, circular, } \\
\text { Flat, uncoated tablet }\end{array}$ \\
\hline 2 & Average Weight & 0.2500 to $0.2700 \mathrm{gm}$ \\
\hline 3 & $\begin{array}{l}\text { Uniformity in } \\
\text { weight }\end{array}$ & $\begin{array}{l}\text { Varaiation not More than } \\
\qquad 5 \%\end{array}$ \\
\hline 4 & Diameter & 8 to $9 \mathrm{~mm}$ \\
\hline 5 & Thickness & 3 to $3.5 \mathrm{~mm}$ \\
\hline 6 & Hardness & 2 to $3.50 \mathrm{Kg} / \mathrm{cm}^{2}$ \\
\hline 7 & Friability & Not more than $1 \%$ \\
\hline 8 & $\begin{array}{l}\text { Disintegration } \\
\text { time }\end{array}$ & 16 to $18 \mathrm{~min}$ \\
\hline 9 & TLC & $\begin{array}{l}\text { Complies the observed } \\
\text { spots }\end{array}$ \\
\hline
\end{tabular}

\section{Conclusion}

Through this present work effort were taken to develop analytical profile of Rajpravartini Vati; which deals with weight variation, hardness, Disintegration time, In fingerprinting, 6 spots at $350 \mathrm{~nm}$ were observed. This piece of work is just a pilot study which can serve as a preliminary step towards standardization of a herbo-mineral drug Rajpravartini Vati. Hence these can used as reference parameters for further pharmaceutical processes. Further study is necessary to explore other parameters related to standardization and quality control.

\section{Aknowledgements}

Author is thankful to Dr.Sarang Deshapande and Tarun Pable sir for providing us all raw material and guidance. Author is thankful to Mr.Gadkari sir, Head of Quality control laboratory of Unijules Life sciences Pvt. Ltd., for helping in Physico-chemical analysis of the drug.

\section{References}

1. http://thscenter.com/ Standardization of Herbal Drugs blog.html accessed on $05 / \overline{0} 1 / \overline{2} 019$ at $\overline{10} 0: 43$.

2. Acharya G.S, Bhaishajya Ratnavali. Varanasi; Chaukhamba Orientalia; 2011; Page No. 233-235.

3. Sharma G. Ayurveda Prakash Suspashtavabodhini. Varanasi; Chaukhambha Bharti Acadamy; 2007; Vol. 2; page no. 275.

4. Mishra S, Ayurvediya Rasashastra. Varanasi; Chaukhamba Orientalia; 2013. Chapter 2; page no. 93.

5. Lachman L et.al The theory \& Practice of Industrial Pharmacy. Vargese Publishing House. $2^{\text {nd }}$ edition:1987; Ch. 5 Page No. 145

6. Heyden YV, Extracting Information fromChromatographic HerbalFingerprints. LCGC Europe. Sept 1 2008; Volume 21, Issue 9; Page no. 213

7. Kokate C.K., Gokhale, S.B. Practical Pharmacognosy. 2nd ed. Pune; NiraliPrakashan; 2001. page no. 14-19.

8. Gupta AK. Introduction to Pharmaceutics - I. 3rd ed. New Delhi; CBS Publishers and Distributors; 1994; page no. 270 . 